PIOTR STEFANIAK* - KRAKÓW

\title{
DEKRETAŁ PAPIEŻA PIUSA XII ŹRÓDŁEM DO DZIEJÓW ŻYCIA ŚW. MALGORZATY WĘGIERSKIEJ OP
}

Młodsza siostra św. Kingi (1234-1292), księżnej krakowskiej, małżonki Bolesława Wstydliwego, po owdowieniu mniszki klariańskiej wStarym Sączu z jednej strony i starsza z drugiej, dla bł. Jolenty (1244-1304), księżnej wielkopolskiej, żony Bolesława Pobożnego i także po owdowieniu klaryski, tym razem gnieźnieńskiej, św. Małgorzata (1242-1270) zajęła w świadomości dziejowej i duchowej naszych węgierskich pobratymców eksponowane miejsce. Z Polską łączyły ją nie tylko postacie dwóch jej sióstr, księżnych polskich oraz osoba starszej siostry bł. Konstancji (1238-1301), żony Daniela Halickiego i po owdowieniu dominikanki we Lwowie, ale także pewien epizod: mianowicie jej ojciec Bela IV planował wydać ją za mąż za księcia kaliskiego, Bolesława zwanego Pobożnym, który ostatecznie w 1256 roku w katedrze wawelskiej poślubił jej młodszą siostrę, bł. Jolentę. Osoba św. Małgorzaty w Polsce nie była zbytnio znaną. Jedynie dominikanie, tak od XVII wieku oddawali jej niewielki i o czysto domowej randze kult, czego odbiciem są dwa obrazy ją wyobrażające w klasztorach poznańskim i krakowskim oraz trzy wizerunki, gdzie występuje ona, dwukrotnie w grupie świętych dominikańskich, raz na drzewie genealogicznym zakonu w atrium klasztoru krakowskiego i drugi w grupie świętych na obrazie z XVII w. z klasztoru lubelskiego oraz po raz trzeci, w grupie świętych dominikanek z klasztoru klimontowskiego. W XIX wieku natomiast wykonano posazzek Małgorzaty, który zdobi kandelabr na ołtarzu głównym krakowskiej bazyliki dominikanów. Ostatnim zaś jej polskim przedstawieniem jest wizerunek na mozaice w Kaplicy Wegierskiej bazyliki Miłosierdzia Bożego w Krakowie-Łagiewnikach, którą wykonał w 2004 roku ks. Laszló Puskás z Budapesztu. Polskojęzyczna literatura hagiograficzna z dawnych wieków omal nie zna Małgorzaty; wyjątek stanowią zbiory świętych powstałe w środowiskach dominikańskich ${ }^{1}$ oraz żywoty świętych Piotra Skargi².

* Piotr Stefaniak - mgr historii, dziennikarz, współprac. Domu Polskiego w Budapeszcie.

${ }^{1}$ Zob. Z. H. Piskorski, Żywoty świętych braci i sióstr Zakonu Kaznodziejskiego, Wilno 1760; M. Sieykowski, Światnica Pańska, Kraków 1743.

${ }^{2}$ Żywoty Świętych Starego i Nowego Zakonu na każdy dzień przez cały rok przez ks. Piotra Skargę uczynione, Kraków 1933, t. 1, s.319-324. 
Dopiero zajmujacy się hagiografią Polacy XX wieku zaczęli ujmować ją w swych zbiorach $^{3}$. Znalazła ona też $\mathrm{w}$ ubiegłym stuleciu miejsce w kilku artykułach prasowych ${ }^{4}$. Jedyna zaś wydana po polsku książka o Małgorzacie pozostaje tłumaczeniem z języka węgierskiego i ukazała się dzięki dominikanom we Lwowie w 1932 roku $^{5}$. Należy ponadto wymienić jeszcze fragmenty legendy o Małgorzacie pióra brata Garinusa, które zostały opublikowane w książce Legendy dominikańskie ${ }^{6}$.

Co zaś się tyczy źródła, które niniejszym zaopatrzono w aparaturę badawczą i wyjaśnienia, to do naszego kraju dotarło wraz z tomem dziewiątym serii drugiej akt Stolicy Apostolskiej za rok 1943, który ukazał się w Rzymie w 1944 roku. Obok tekstu, który został właśnie przetłumaczony przez autora, w Polsce znane jest thumaczenie, którego maszynopis sporządzony zapewnie w końcu lat czterdziestych XX wieku znajduje się w zasobie klasztoru dominikanek w Świętej Annie w województwie śląskim ${ }^{7}$, oraz fragmenty innego thumacza, które zostały wykorzystane do studyjnego wydania dodatków własnych Zakonu Kaznodziejskiego Polskiej Prowincji do ogólnokościelnej Liturgii Godzin ${ }^{8}$. Przystępując do własnej wersji thumaczenia autor znał oba teksty. Służyły one mu do konfrontacji z jego pracą. Zwłaszcza tekst z klasztoru Świętej Anny stał się pomocny, mimo, że jest on napisany nieco archaiczną już polszczyzna, jednak znakomicie ujmuje on zwroty kościelne i znacznie lepiej wnika, niż fragmentaryczne thumaczenie $\mathrm{z}$ dodatku do brewiarza $\mathrm{w}$ ducha dokumentu. Niniejsze tłumaczenie w swym zamyśle ma współczesnym językiem oddać treści spisane w połowie ubiegłego stulecia z zachowaniem pewnej dostojności formy i specyfiki kościelnych wyrażeń dokumentów papieskich, tak jednak, aby nie raziły one zarzuconą już formą polszczyzny. Różnice w tłumaczeniu niniejszym od poprzednich wynikają wyłącznie z formy językowej. I tak, w przypadku tekstu z klasztoru w Świętej Annie dostosowano go do języka współczesnego i skorygowano z zasadami wystawiania dekretałów, a w przypadku fragmentu z oficjum dominikańskiego różnica polega na zrezygnowaniu z wręcz kalki translatorskiej charakteryzującej ten tekst i skupieniu się na formie bardziej oddającej ducha dokumentu, niż składni łacińskiej tłumaczonej na język polski.

${ }^{3}$ Żywoty Świętych Pańskich ... ułożyt ks. Władysław Hozakowski, Poznań 1908: na str. 85-87 znajduje się żywot $\dot{S}$. Matgorzaty, królewny wegierskiej, dziewicy (1243-1271). Ta pozycja jest o tyle ciekawa, że posiada w swym zbiorze niezwykłą rzadkość - dotąd Autor nie znalazł podobnej sytuacji - jeszcze żywoty trzech sióstr św. Małgorzaty, Kingi (s. 657-659), Jolenty (s. 521-524) i Konstancji (s. 300-301).

${ }^{4}$ J., Św. Małgorzata królewna dominikanka (1242-1270), w: „Róża Duchowna”, 1 (1949) s. 11; Bt. Małgorzata Węierska, SiostraŚw. Kingi, KrólowejPolskiej, P.Z.K., w: „RóżaDuchowna”, 5(1902) s. 9-11; S. A. Sroka, Księżniczka z wyspy, w: „Miejsca Święte”, 3 (2004) s. 22-23.; P. Stefaniak, Matgorzata-perła w węgierskiej koronie, w: „Źródło”, 3 (2004) s. 16.

${ }^{5}$ K. Böle, Życiorys bt. Małgorzaty (królewny-dominikanki), Lwów 1932.

${ }^{6}$ Legendy dominikańskie, przeł. i oprac. J. Salij, Poznań 1983, s. 101-106.

${ }^{7}$ Biblioteka Nowicjatu Klasztoru SS Dominikanek w Świętej Annie, mps. sygn. BN sd/149.

${ }^{8}$ Liturgia Godzin Polskiej Prowincji Zakonu Kaznodziejskiego, Styczeń, Warszawa 2003, s. 25-32. 
Dekretał jako pismo papieskie zawierające rozporządzenia receptywne, czyli nakazujace, bądź zakazujące, kierowane jest do pojedynczych osób, lub całych społecznośc i wydawane jest głównie w sprawach dyscyplinarnych ${ }^{9}$. Z tego rodzaju formy prawnej skorzystał Pius XII, aby na prośbę Kościoła węgierskiego w okresie trwającej wojny, dokonać szybkiego wyniesienia na ołtarze królewny, którą wówczas uważano za partonkę upragnionego pokoju. Dekretał więc sprawnie i z pominięciem żmudnej procedury formalnej kanonizacji, co nie oznacza wcale, że akta kanonizacyjne były niekompletne, lub niewystarczajace, ustanawiał fakt kanonizacji równoważnej. Dokument dotyczący ogłoszenia Małgorzaty święta, będąc $\mathrm{z}$ jednej strony ważkim prawnym dokumentem kościelnym stwierdzającym formalność i kanoniczność kultu oddawanego Arpadównie pozostaje także z perspektywy oczekiwań historyków źródłem mocno osadzonym na materiale archiwalnym i przekazie sięgającym często jeszcze XIII stulecia. Wiadomo, że papieżowi Piusowi XII, a raczej stosownej kongregacji watykańskiej, postulator kanonizacji Kornel Bőle OP dostarczył kopie dostępnych archiwaliów. Były to przede wszystkim teksty najstarszych legend o życiu Małgorzaty. $Z$ trzynastego stulecia pochodzily trzy wersje legendy pióra brata Marcellusa Quedam legenda beate Margarite de Ungaria (z 1271, 1274 i z lat 1276-1300), dwa protokoły do procesu kanonizacyjnego powstałe w latach 1272-1274 i w 1276 oraz legendy powstałe później w oparciu o wymienione. Były to: Legenda Wegierska z lat 1300-1320, jej kopia z lat 1360-1409 i kopia pióra mniszki dominikańskiej z Wyspy Małgorzaty, Lei Raskai z 1510 r., oraz legenda z XV w. pióra brata Ranzanusa, oraz pięć tekstów późniejszych (Historia z 1300, czternastowieczna Legenda z klasztoru dominikanek z Töss w Szwajcarii, Legenda brata Garinusa z 1340, Legenda Neapolitańska z drugiej połowy XIV w., oraz jej kopia, czyli tzw. Speculum $^{10}$.

Artykuł zatem ma ambicje za pomocą przypisów wykazać faktograficzną wartość dekretału i wyjaśnienie pewnych nieścisłości, które się wkradły w jego treść. Niech owoce tej pracy, jak pragnie tego autor, będą kolejnymi z licznych inicjatyw pielęgnujących polsko-węgierskie więzi braterstwa i przyjaźni, które trwają nieprzerwanie od ponad tysiąca lat naszych wspólnych dziejów.

${ }^{9}$ Zob. biogram dekretałów w: Encyklopedia Katolicka, red. R. Łukaszak, Lublin 1995, t. 3, kol. $1120-1121$.

${ }^{10}$ M. Frąckowiak, Życie i kult świętej Matgorzaty Węgierskiej,praca magisterska na wydziale Neofilologii Uniwersytetu im. A. Mickiewicza w Poznaniu z roku 1997 napisana pod kierunkiem prof. A. Karłowskiej-Kamzowej 
ACTA APOSTOLICAE SEDIS

COMMENTARIUM OFFICIALE

ANNUS XXXVI - SERIES II - VOL. XI

AKTA STOLICY APOSTOLSKIEJ

DZIENNIK URZĘDOWY

ROK 36 - SERIA 2 - T. 11

TYPIS POLYGLOTTIS VATICANIS

M. DCCCC. XLIV

r. it. 36

23 lutego 1944 (ser. 2, t. 11) - nr 2

AKTA STOLICY APOSTOLSKIEJ

DZIENNIK URZĘDOWY

Akta Papieża Piusa XII

DEKRETAE

WPISANIE BŁOGOSŁAWIONEJ MAŁGORZATY DZIEWICY, Z KRÓLEWSKIEJ RODZINY WĘGIERSKICH ARPADÓW, MNISZKI ZAKONU ŚW. DOMINIKA, DO KATALOGU SWIĘTYCH

PIUS BISKUP

SŁUGA SŁUG BOZYCH

NA WIECZNĄ RZECZY PAMIĄTKĘ

Wśród bardzo wielkich obowiazków, które staramy się dopełnić na Urzędzie Apostolskim, nam, choć niezasłużenie, od Boga powierzonym, nie ma zaiste ważniejszego, ani słodszego, któryby większą w czasie różnych trosk i niepokojów niósł pociechę, jak przyznawanie najwyższych oznak czci tym wiernym, którzy za życia zajaśnieli wszelkiego rodzaju cnotami aż po stopień doskonałości, zasłynęli cudami zdziałanymi przez Boga wszechmogącego za ich wstawiennictwem i słusznie osiagnnęli stałą opinię świętości. Papieże Rzymscy pod tchnieniem Ducha Bożego aż do naszych czasów ku radości całego świata katolickiego czynili to z tym większym staraniem i częstością, im więcej lud chrześcijański zdawał się wymagać wstawienników i przesławnych przykładów cnót.

Ostatnio między nich uznaliśmy słusznie i zasłużenie zaliczyć ową Błogosławioną Dziewicę, ozdobę katolickiego narodu Węgrów, Małgorzatę, córkę króla Béli Czwartego, mniszkę sławnego Zakonu Św. Dominika, już wtedy [s. 34] posiadajqca starożytny kult, a o jej heroicznych cnotach $i$ cudach istnieje state prze- 
konanie wiarygodnych historyków oraz nie brak nieprzerwanej sławy z powodów cudów, dlatego prawdziwie zdaje się być godną, abyśmy My, chociaż nie przez formalną i zwyczajną kanonizacją uroczysta, ale Naszym najwyższym orzeczeniem ogłosili ją Świętą i nakazali wpisać do Katalogu Świętych. Pochodziła z królewskiego rodu węgierskich Arpadów, który sam w jednym tylko wieku trzynastym zrodził Kościołowi Bożemu cztery zaiste przeczystego żywota niewiasty, mianowicie Św. Elżbietę ${ }^{11}$, roku tysiącznego dwusetnego trzydziestego czwartego ${ }^{12}$ między świętych policzoną przez Naszego Poprzednika, Grzegorza Ósmego, Bł. Agnieszkę Praską ${ }^{13}$, jej siostrę cioteczną i córki Béli Czwartego, Kingę i Jolentę, których cześć Stolica Apostolska zaaprobowała pierwej niż Małgorzaty ${ }^{14}$. Roku tysiącznego dwusetnego czterdziestego drugiego, kiedy Tatarzy pod wodzą Batu-chana ogniem i mieczem pustoszyli Polskę i Pannonię, a Węgry zroszone tylokrotnie krwią chrześcijańską uległy największemu spustoszeniu, z pobożnych rodziców, Béli Czwartego, Króla Węgrów i królowej Marii Laskaris, po schronie-

${ }^{11}$ Święta Elżbieta Węgierska (1207-1231), małżonka świątobliwego Ludwika, grafa Turyngii była drugą córka (trzecim dzieckiem) króla Andrzeja II i Gertrudy Andechs Meran, siostry św. Jadwigi Śląskiej. Jako dziecko skierowana na dwór męża z którym stworzyła szczęśliwa rodzinę. Święta Elżbieta była matką trojga dzieci, Zofii, Hermana i bł. Gertrudy, późniejszej mistyczki z klasztoru norbertanek w heskim Altenbergu. Zasłynęła szeroko ze swej pobożności i heroicznej wręcz ofiarności względem ubogich. Owdowiała w 1227 r. po śmierci męża, który udał się na wyprawę krzyżową i usunęła się z zamku Wartburg do ufundowanego przez siebie szpitala w Marburgu. Tam posługując chorym i starym wiodła pod kierunkiem spowiedników, najpierw surowego franciszkanina Rudygiera, następnie dominikanina Konrada, surowy żywot. W swym skrajnie ascetycznym życiu realizowała syntezę duchowości dominikańskiej i franciszkańskiej. Jej przynależność do tercjarstwa u minorytów choć bardzo popularna nie znajduje odzwierciedlenia w źródłach. Elżbieta zmarła w marburskim przytułku 17 listopada 1231 r. mając 26 lat. Została kanonizowana w 1235 i w średniowieczu cieszyła się niezwykle żywym kultem, zwłaszcza w środowiskach feudałów z obszaru Europy Środkowo-Wschodniej. Zob. Summa vitae [S. Elizabeth], w: Hessische Urkundenbuch, Leipzig 1897.

${ }^{12} \mathrm{~W}$ tekście nastąpiła pomyłka, gdyż kanonizacji Elżbiety dokonał papież Grzegorz IX 27 maja 1235 roku w Perugii. Zob. P. Stefaniak, Elżbieta Arpadówna, księżna Turyngii, „Źródło”, 46 (2004) s. 12.

${ }^{13}$ Święta Agnieszka Przemyślidówna (1211-1282), córka króla czeskiego Przemysła I Ottokara i Konstancji Arpadówny, córki króla węgierskiego Beli III i siostry Andrzeja II. Należała ona do dynastii Przemyślidów nie zaś Arpadów. $\mathrm{Z}$ tą ostatnią dynastią powiązana była poprzez matkę. Dzieciństwo spędziła w opactwie trzebnickim, potem udała się na wiedeński dwór narzeczonego księcia Leopolda. Nie została jego małżonka, ani następnie cesarza Fryderyka II, tylko w 1234 r. przywdziała habit w ufundowanym przez siebie klasztorze klarysek w Pradze. Stanęła na jego czele jako ksieni, prowadziła korespondencję ze św. Klarą z Asyżu i dla swej wspólnoty wywalczyła przywilej ścisłego ubóstwa na wzór klasztoru klarysek asyskich. Zmarła 2 marca 1282 roku. Beatyfikowana w 1874 roku i kanonizowana w 1989 r. Zob. Najstarsza „Legenda” o św. Agnieszce z Pragi, „W nurcie franciszkańskim”, 3 (1993) s. 91-113.

${ }^{14}$ Beatyfikacja Kingi miała miejsce 11 czerwca 1690 r. i dokonał jej papież Aleksander VIII, natomiast beatyfikacji Jolanty w formie zatwierdzenia kultu dokonał papież Leon XIII 26 września $1827 \mathrm{r}$. 
niu się na zamku w Dalmacji, urodziła się Błogosławiona Małgorzata ${ }^{15}$. Poczęte dziecię - jeśli urodzi się córką - rodzice ofiarowali jak gdyby na ofiarę przebłagalną Bogu za wyzwolenie królestwa i swoje ocalenie ${ }^{16}$; modlitwy ich i śluby zostały wysłuchane, albowiem po nagłym uspokojeniu się wszystkiego mogli oni razem $\mathrm{z}$ nowonarodzoną Małgorzatą powrócić do Budy. Kiedy więc tym sposobem stała się jeszcze w łonie matczynym opiekunką królestwa swych przodków, dobra matka mając w pamięci swoją obietnicę i łaskę doznana, przywiodła ją do klasztoru św. Katarzyny Panny i Męczenniczki świętych mniszek «Zakonu Sw. Dominika» w Veszprém przed ukończeniem czwartego roku życia, aby już od maleńkości mogła się uczyć zwyczajów zakonnych i stosowniej służyła Bogu ${ }^{17}$. Tutaj zapominając o swym królewskim pochodzeniu, Małgorzata całym sercem stała się uczennicą Krzyża, tak też zasłynęła duchem uległości i posłuszeństwem, że mniszki otaczały ją najtkliwszą miłością; ona zaś pomimo dziecięcego wieku odznaczała się anielską pobożnością ku Jezusowi i Maryi; okazywała nadzwyczajne obyczaje i czystość duszy; i od tego czasu zasłużyła na to, że Król królów zapragnął jej piękna.

Mając zaledwie pięć lat, chciała razem z siostrami używać dyscypliny, pościć i nosić włosiennicę. Dlatego król, ojciec jej, skoro tylko naród węgierski obronił się przed napadami Tatarów, aby pewniej i skuteczniej sobie i swemu królestwu wyjednywać pomoc Bożą wybudował na wyspie na Dunaju, dawniej zwaną Zaję$c z q$, a dziś Św. Małgorzaty ${ }^{18}$, klasztor ku czci Błogosławionej Dziewicy Maryi, w którym nie tylko postarał się o umieszczenie tam pobożnych poświęconych dziewic, mających oddawać się samemu Bogu jako żywe hostie i śpiewać Jemu

${ }^{15}$ Narodziny miały miejsce na zamku Klissza (Klis) koło Splitu w Dalmacji, gdzie miała się zatrzymać królowa Maria Laskaris wraz z dziećmi i dworem podczas ucieczki przed nawałą tatarską. Zob. A. Gábriel, Magyarországi Szent Margit, Budapest 1944, s.12; Árpádházi boldog Margit. A Margit-legenda Nyomán, Budapest 1915, s. 10. Krakowski historyk średniowiecza, specjalista od spraw Węgier, Stanisław Sroka podał datę dzienną narodzin Małgorzaty: 27 stycznia 1242 roku. Zob. Sroka, Księżniczka z wyspy, s. 22.

${ }^{16}$ Legenda pióra brata Garinusa podaje szczegóły ofiarowania Bogu Małgorzaty przez pare królewską w ofierze za naród. Zob. Brat Garinus, Złożona za naród, w: Legendy dominikańskie, s. 103.

${ }^{17}$ Vita Latina Anonyma, alias Ioanni de Vercelli Magistro Generali Ordinis Praedicatorum tributa, e saecundo XIII exuente, w: Inquisitio iussu Sanctissimi Domini Nostri Pii Papae XII peracta De Vita beatae Margaritae ab Hungariae sanctimonialis ordinis praedicatorum deque cultu ei praestito, Roma 1944, s. 162.

${ }^{18} \mathrm{Na}$ Dunaju na wysokości Budy i Pesztu znajduje się wyspa, która od wczesnego średniowiecza była użytkowana przez zakony (dominikanów, dominikanek, joannitów, norbertanów, norbertanki i franciszkanów) oraz przez władców Węgier, którzy tutaj posiadali swój zamek. Przez wieki wyspa nosiła kilka nazw: najstarszą była Wyspa Zajęcza, następnie Błogosławionej Dziewicy Maryi na cześć wezwania kościoła dominikanek. Po śmierci św. Małgorzaty wyspę nazwano jej imieniem. W XVIII w. określana była Wyspą Namiestnika, od funkcji księcia Habsburga, namiestnika Węgier. Obecnie wyspa nosi napowrót nazwę Małgorzaty i pozostaje rekreacyjną enklawą w kilkumilionowym Budapeszcie. Przyp. aut. 
i Matce Bożej chwałę, [s.35] ale także umieścił swoją córkę, Małgorzatę ${ }^{19}$, którq spośród innych swych dzieci najczulszym darzyt uczuciem, dostrzegajac w niej zaczatki świętego i Bogu miłego życia ${ }^{20}$.

Tymczasem ona, która zdawała się mieć za własne słowa Apostoła: Uważam wszystko za szkode wobec niezrównanej znajomości Jezusa Chrystusa Pana mego, dla którego wyzułem się z tego wszystkiego i mam to sobie za śmieci, abym Chrystusa zyskat, odmówiła oddania ręki pewnemu Księciu Polskiemu ${ }^{21}$ i w dwunastym roku życia złożyła uroczyste śluby zakonne na ręce czcigodnego Mistrza Zakonu, Humberta ${ }^{22}$. Ponadto, gdy Ottokar Król Czech prosił usilnie o jej rękę ${ }^{23}$, postanowiła publicznie zostać zaślubioną Chrystusowi, aby za wszelką cenę zachować nienaruszoną wierność swojemu Boskiemu Oblubieńcowi i raz na zawsze położyć kres wszelkim naleganiom o zawarcie małżeństwa, poprosiła o święty welon i otrzymała go dnia czternastego czerwca roku tysiącznego dwusetnego sześćdziesiątego pierwszego z rąk Arcybiskupa Ostrzyhomskiego w obecności Biskupów z Vác i Nitry, oraz wielu dostojników kościelnych przy ołtarzu św. Elżbiety, swej stryjenki ${ }^{24}$. W ten sposób poślubiona Oblubieńcowi Dziewic, gorli-

${ }^{19}$ Bela IV w wystawionym przez siebie dokumencie tak motywował wzniesienie na Wyspie Zajęczej klasztoru mniszek dominikańskich i umieszczenie w nim swej córki Małgorzaty: Et ut devotio nostra Deo, quem latere nihil potest, cognita, etiam ceteris proponeretur in exemplum et in lucem proferretur devotionis in subditis propagandae, filiam nostram, Dominam Margaretham, quam inter alios nostros liberos eo teneriori amplexamur affectu, quo certiora piae et Deo placitae conversationis in ea primordia cernebamus, in ipso monasterio posuimus, Deo, quoad viveret, et gloriosae Virgini servituam. Zob.G. Fejér, Codex diplomaticus Hungariae ecclesiasticae et civilis, Budapest 1829, t. IV, vol. II, s. 321. Małgorzata w 1252 r. przybyła na Wyspę Zajęczą mając 10 lat.

${ }^{20}$ Teksty kursywą sa cytatami z najstarszych żywotów św. Małgorzaty, zwłaszcza z legendy napisanej przez brata Garinusa.

${ }^{21}$ Chodziło o księcia wielkopolskiego, Bolesław Pobożnego (1220/1224-1279), który ostatecznie w 1256 r. poślubił na Wawelu najmłodszą siostrę Małgorzaty, bł. Jolentę. Zob. Rocznik Traski, w: Monumenta Poloniae Historica, t. 4, s. 582.

${ }^{22} \mathrm{~B}$. Humbert $\mathrm{z}$ Romains był genrerałem dominikanów w latach 1254-1264 i jako piąty następca św. Dominika został obrany na kapitule generalnej zakonu, która obradowała w Budzie, w klasztorze św. Mikołaja w 1254 r. wówczas też nadarzyła się okazją, by 12 letnia Małgorzata bezposrednio na jego ręce złożyła swą profesję zakonną. Sam fakt ślubów Arpadówny jest znany głównie z Incipitu Vita Beate Margarete de Ungaria Ordinis Praedicatorum z Vita Latina Anonyma, alias Ioanni de Vercelli Magistro Generali Ordinis Praedicatorum tributa, w: Inquisitio, s. 162: Ubi cum, facta professione cum suis sororibus in manibus fratri Umberthi, tunc magistri ordinis, esset inclusa ut moris est claustris sororum nostro ordini incorporatarum.

${ }^{23} \mathrm{~W} 1260$ r. został podpisany układ kończący wojnę Beli IV z Przemysłem II Ottokarem o spadek po Babenbergach. Jego umocnieniem miał być ślub Małgorzaty z królem czeskim, jednak ona stanowczo odmówiła zamążpójścia i ostatecznie Przemyślida poślubił wnuczkę króla Węgier księżniczkę Kunegundę, córkę Rościsława czernihowskiego i Anny Arpadówny, starszej siostry św. Małgorzaty. Zob. K. Jörg, Premysl Otakar II. Von Böhmen. Der goldene König, Graz Wien Köln 1989, s. 120 .

${ }^{24}$ Vita Latina Anonyma..., dz. cyt., s.167; Excerpta ex Processu Apostolico super vita et miraculis B. Margaritae, constructo anno 1276, w: Inqiusitio, s. 11: Testis I Domina Catharina Priorissa Monasterii de Insula Danubii; Excerpta, s. 16: Testis II Domina Eliana Monialis eiusdem Monasterii. 
wie starała się upodabniać do Króla Męczenników poprzez wzgardą samej siebie, świata, oraz umartwianiem ciała. Odrzuciwszy urzędy zawsze chodziła w najgorszym ubraniu i domagała się dla siebie najniższych prac, a za największą rozkosz uważała zamiatanie domu, usuwanie brudu, gotowanie posiłków oraz częste noszenie ciężarów. $Z$ tak wielką miłością i samozaparciem usługiwała chorym siostrom i służącym, do których inne bały się zbliżyć ze względu na możliwość zarażenia się, że sama jedna wykonywała, zarezerwowane dla siebie, przy nich wszystkie najniższe i najnieprzyjemniejsze prace ${ }^{25}$.

Za nic miała sobie to, że jej ręce pod wpływem mrozu, łokcie i kolana od rzucania się na ziemię, puchły i tworzyły rany, ciało, i tak już bardzo umartwiane postami, dręczyła włosiennica, biczowaniami i bezsennymi nocami, szczególnie w piątki i wigilie świąt Chrystusa Pana i Matki Boskiej, oraz przez dwa tygodnie poprzedzające Wielkanoc. Ze łzami rozważała tajemnice Męki Pańskiej i pałała pragnieniem męczeństwa. Chociaż chętniej lubiła przed Panem Jezusem, czy to utajonym pod osłonami eucharystycznymi, czy też rozpiętym na krzyżu, codziennie długie godziny spędzać wylewając uczucia swego serca, to jednak modliła się wszędzie i niemal bez przerwy, nierzadko do obowiązkowego oficjum dodawała cały psałterz, modlitwy do Boga Ojca, do Ducha Świętego Pocieszyciela, albo pozdrowienie swej najukochańszej Dziewiczej Bożej Rodzicielki. Mówią, że przez ustawiczny wysiłek osiagnęła wszystkie cnoty w stopniu heroicznym, przede wszystkim teologiczne, i w tymże ćwiczeniu wytrwała aż do śmierci, tak, że dla pozostałych była bardzo wielką zachętą do cnoty.

Cnota Małgorzaty miała się ukazać w pełni w czasie zaciekłej wojny, jaka wybuchła między jej ojcem, Królem Bélą Czwartym i bratem, Stefanem [s.36] o rządy w królestwie oraz o następstwo tronu, i trwała prawie przez cztery lata; $\mathrm{w}$ niej to, z pogwatceniem wszelkiego porzadku sprawiedliwości $i$ ze wzgarda bojaźni Bożej, tak przez dostojników kościelnych, jak i świeckich, wiele tysięcy niewinnych zginęto niesprawiedliwie ${ }^{26}$.

Ta klęska nieszczęsna dręczyła serce Małgorzaty do tego stopnia, że wylewała tzy dniem i noca; widziała bowiem rodzinę swoją poszarpaną niezgodą lub też w niebezpieczeństwie, patrzyła jak uciskani są ludzie bez względu na wiek i płeć, a nawet świętą matkę Kościół nie tylko w tym królestwie, lecz również i w innych częściach chrześcijaństwa deptaną i szarpaną przez tyranię; klasztory opuszczone przez zakonników, a wszelkie prawo Boskie i ludzkie bezbożnie skłócone. Aby przebłagać gniew wszechmogącego Boga i wyjednać dla swojego narodu miłosierdzie Boże, sama jeszcze obficiej ronita tzy $i$ umartwiata swe ciato postami $i$ wtosiennica, pokutują jakby za grzechy wszystkich ludzi, którzy tak niespra-

${ }^{25}$ Excerpta, passim (zeznania sióstr, np. Jolenty, Małgorzaty Rurykowiczówny, córki księżnej Anny, siostry św. Małgorzaty, Elżbiety, córki Stefana V, Sabiny z Budy, Elżbiety de Bodomer, Olimpiades de Bodomer, Frozji z Nitry, Judyty Hyppoliti czy konwerski Agnieszki).

${ }^{26} \mathrm{~W}$ latach 1254-1260 rex iunior Stefan wojował z ojcem Belą IV o wpływy w państwie. Młodszy władca wdał się w rozgrywkę między stronnictwami magnackimi, które prowadziły własną politykę i pragnęły osłabienia władzy króla Beli IV. Wojna domowa była bardzo krwawa, doszło w niej także do uwięzienia przez Belę IV synowej i wnucząt, stanowiących rodzinę Stefana. zob. I. Lazar, Kleine Geschichte Ungarns, Wien 1990, s. 75. 
wiedliwie postępuja wobec Boga oraz bolejac nad nieszczęściem uciśnionych. Cata bez reszty oddawata sie usilnej modlitwie, aby Pan Jezus Chrystus moca swojej prawicy bronit niewinnych oraz święta matkę Kościót, którq swoja własna krwiq zgromadzit w jedno.

Otóż Małgorzata nie ograniczała swego działania jedynie do płomiennych błagań zanoszonych do Boga, czy do najsurowszej pokuty, lecz także zapalona apostolską gorliwością i umocniona heroicznym męstwem nie wahała się otwarcie piętnować niesprawiedliwości, dokonywanej przez kogokolwiek, choćby nawet przez najwyższego władzą lub godnością; skutkiem tego ściągnęła na siebie gniew ojca i gdy kiedyś odrzucała pochlebstwa, teraz musiała cierpieć nawet prześladowania ${ }^{27}$; nie dbała jednak o to zupełnie i zniosła je nieustraszenie nie porzucając swego działania: gromienia ludzkiej nieprawości a także godzenia przeciwników.

Jej modlitwy, tak obficie do Boga zanoszone, połączone z umartwianiem jej dziewiczego ciała w końcu zostały przez Najwyższego wysłuchane; nastapił pokój między ojcem a bratem, co uroczyście przypieczętowano na wyspie Zajęczej, w samym klasztorze uświęconym obecnością Małgorzaty w roku Pańskim tysiącznym dwusetnym sześćdziesiątym szóstym ${ }^{28}$.

Celem coraz większego utwierdzenia pokoju w królestwie Król Béla postanowił rodzinę swoją skoligacić z Karolem, hrabią Andegawenii, który w roku tysiącznym dwusetnym sześćdziesiątym szóstym został Królem Neapolu; stąd też córce swej Małgorzacie zaproponował małżeństwo z nim, dodając równocześnie, że od Papieża Klemensa Czwartego łatwo dla niej uzyska dyspensę od ślubów zakonnych ${ }^{29}$. Małgorzata po raz trzeci odrzuciła proponowane jej zamążpójście, otwarcie odpowiadając, że pragnie zachować swoje [s. 37] dziewictwo dla Pana Jezusa Chrystusa. A ten Boski Oblubieniec, zawsze wierny i wspaniałomyślny, znalazł słodkie mieszkanie w sercu swojej służebnicy i napełnił ją najobficiej swoimi nadprzyrodzonymi darami, czyniąc towarzyszką swojej męki oraz współuczestniczką pocieszenia i mocy za życia i po śmierci.

Opowiadają bowiem, że ona już w dzieciństwie zwykła była prorokować i w czasie mszy świętej odchodzić od zmysłów, poznawała też tajniki serc i dzięki mocy Bożej dokonała nie mało uzdrowień i cudów.

Wiedząc wreszcie o bliskiej swej śmierci prosiła gorąco o ostatnie sakramenty Kościoła i wedle swego pragnienia kilkakroć je otrzymywała, przyjmując je $\mathrm{z}$ anielską miłością w dzień wspomnienia św. Pryski roku tysiącznego dwusetnego siedemdziesiątego, nie mając jeszcze lat trzydziestu swego życia ozdobiona

${ }^{27}$ Böle, Życiorys bt. Jolenty, s. 130.

${ }^{28} \mathrm{~W} 1266$ roku w klasztorze dominikanek w Budzie został podpisany pokój kończący dwuletnią wojnę domową pomiędzy stronnictwami króla Beli IV a jego synem Stefanem V. Układ został zawarty dzięki mediacji jakiej podjęły się córki i wnuczki króla Beli IV, w tym święte Kinga, Małgorzata, Konstancja i Jolenta.

${ }^{29}$ Układ dynastyczny z Andegawenami miał zaowocować podwójnymi małżeństwami: Arpadówna miała poślubić króla Karola I, a jego córka Izabella miała zostać żoną wnuka Beli IV, Władysława. Tymczasem wobec oporu Małgorzaty nastąpiła korekta: Karol II Andegawen ożenił się z Marią, wnuczką władcy węgierskiego. 
koroną Chrystusa weszła do nieba ${ }^{30}$. Dziewicze jej ciało, ozdoba przyszłego zmartwychwstania, wydające $\mathrm{z}$ siebie słodką woń, uroczyście zostało z grobu wydobyte, i jak powiadajac niosło lekarstwo chorobom błagających o uzdrowienie: opowiadają o wielu cudach i łaskach uzyskanych za wstawiennictwem Sługi Bożej aż do czasów obecnych.

Nie dziwota więc, że imię Małgorzaty bardzo sławne jest nie tylko na Węgrzech, które jako swą ojczyznę przyozdobiła słodyczą cnót heroicznych, blaskiem świętości i chwałą cudów, lecz również poza ich granicami, szczególnie dzięki Zakonowi Kaznodziejskiemu, który chlubi się, że wzrósł za wstawiennictwem Błogosławionej, imię jej stało się chwalebne, czy to dzięki legendom, które rozpowszechniły się o Małgorzacie jako o świętej zaraz po jej zgonie, czy też dzięki procesowi apostolskiemu w sześć lat po śmierci królewskiej Dziewicy rozpoczętemu, w którym tytuł Błogosławionej albo Świętej bardzo często przydawany był Małgorzacie i powagą władz kościelnych, nawet najwyższych postanowiony.

Cześć zaś oddawana tej Słudze Bożej rozpoczęta zaraz po jej zgonie, jaśniejąc coraz to nowym światłem dotrwała aż do naszych czasów. Widać to najwyraźniej tak z jej życiorysów napisanych w różnych językach, jak i z zabytków; między innymi istnieje drogocenny płaszcz ofiarowany, jak powiadaja, przez Elżbietę ${ }^{31}$, Królową Węgier, Naszej Bazylice Św. Piotra w roku tysiącznym trzechsetnym czterdziestym trzecim; na owym płaszczu razem z Bł. Dziewicą Maryją, Św. Apostołami Piotrem i Pawłem, wizerunkami czterech postaci Świętych z węierskiej rodziny królewskiej widać także obraz Małgorzaty, córki Króla Węgier, której nadano miano Świętej; także z nabożeństw wiernych odprawianych u grobu i relikwii Sługi Bożej; również z licznych obrazów przedstawiających Błogosławiona, które z biegiem czasu mnożyły się coraz liczniej, a którym to oddawano publiczną cześć [s. 38]; podobnie ze świętem, w którym lud Węgierski czci pamięć Błogosławionej i okazuje jej swoje gorące nabożeństwo.

Wynika to przede wszystkim z pozwolenia udzielonego od Stolicy Apostolskiej Diecezji Siedmiogrodu w roku tysiącznym siedemsetnym osiemdziesiątym

${ }^{30}$ Excerpta, s. 157; Gábriel, Magyarország, s. 14: dzień wspomnienia św. Pryski czyli 18 stycznia.

${ }^{31}$ Chodzi tutaj o królową Elżbietę Łokietkównę (1305-1380), córkę Władysława Łokietka, króla polskiego i Jadwigi Piastówny wielkopolskiej, córki Bolesława Pobożnego i bł. Jolenty Arpadówny, córki Béli IV i siostry św. Małgorzaty. Elżbieta Łokietkówna od 1320 r. była żoną króla Węgier, Karola Roberta Anjou i w imieniu syna Ludwika pełniła regencję w Polsce (w latach 1370-1379). Jako starsza królowa polska Elżbieta kontynuowała w Polsce politykę swego zmarłego brata, króla Kazimierza III Wielkiego. Ponadto w ramach unii personalnej Węgier i Polski występowała przeciwko sojuszowi luksembursko-krzyżackiemu. W 1374 r. przyczyniła się do podpisaniu układu w Koszycach na mocy którego tron polski mógł być dziedziczony po kądzieli, czym zawarowano prawo do korony wnuczkom Elzbiety, córkom Ludwika Wegierskiego (najpierw Marii i ostatecznie św. Jadwidze). Elżbieta zapamiętana została także jako pierwsza władczyni, która stosowała niedawno wynalezione perfumy. Pobyt królowej we Włoszech, przy okazji którego Stolicy Apostolskiej uczyniła dar, spowodowany był aspiracjami dynastycznymi Andegawenów węgierskich w stosunku do tronu neapolitańskiego; chodziło o osadzenie na tronie i ugruntowanie panowania w Neapolu u boku Joanny królewicza Andrzeja, syna Karola Roberta i Elżbiety Łokietkówny. Zob. S. Sroka, Historia Wegier do 1526 roku w zarysie, Bydgoszcz 2000. 
dziewiątym przez Poprzednika Naszego papieża Piusa szóstego na odmawianie oficjum $^{32}$ i odprawianie Mszy o owej Błogosławionej Dziewicy ${ }^{33}$; pozwolenie to Papież Pius Siódmy rozciąną̧ na cały Zakon Kaznodziejski roku tysiącznego osiemsetnego czwartego ${ }^{34}$; stąd to święto Błogosławionej po raz pierwszy w tym zakonie i w samym Mieście Naszym [Rzymie], w Bazylice Św. Maryi nad świątynią Minerwy było uroczyście z wielką pompą sprawowane roku następnego w dniu dwudziestym szóstym miesiąca stycznia ${ }^{35}$.

Gdy więc zdawało się, że zachodzą wedle norm ustalonych przez najmądrzejszego poprzednika naszego papieża Benedykta XIV, warunki wymagane do kanonizacji równoważnej w stosunku do Błogosławionej Małgorzaty, ukochany Syn nasz, Justynian Św. Rz. K. Kardynał Serédi, książę Prymas Węgier i Arcybiskup Ostrzyhomski ${ }^{36}$, imieniem wszystkich kapłanów Węgier, umiłowanych Synów Rządców Królestwa Węgierskiego i Książąt, a także prawie całego Narodu Węgierskiego, razem z Mistrzem Generalnym Zakonu Kaznodziejskiego i niezliczonymi Kardynałami, Biskupami i rodzinami zakonnymi całego świata katolickiego wnieśli do Nas błagalne prośby, jak najgoręcej domagając się abyśmy pełnią Naszej Apostolskiej władzy raczyli wpisać Błogosławioną Dziewicę Małgorzatę do katalogu Świętych.

My więc te prośby życzliwie i jak najchętniej przyjmując, poruczyliśmy Świętej Kongregacji Rytów rzecz do pełnego zbadania i wykonania, i to tym wię-

${ }^{32}$ Kapłańskie Pacierze o Małgorzacie, czyli Officium rhythmicum Beatae Margarithae, w: Biblioteka Narodowa Węgier w Budapeszcie, rps. nr 5, Gömöry (z XV w.). Po raz pierwszy drukiem opublikował i do kultu je przeznaczył komisarz generalny dominikanów na Węgrzech, Zygmunt Ferrarius w wydanym w 1637 r. dziele: Officium in Festo B. Margaritae, die 18 Ianuarii, decantari solitum ab Ordine praedicatorum in Hungaria, Viennae Austriae 1637. Owo Oficjum ostatecznie zaaprobował jako obowiązujące na terenie diecezji Siedmiogrodu papież Pius VI w 1789 r. Ten akt jest jakby pierwszym orzeczeniem, iż Małgorzatę kanonicznie uznano błogosławioną. Zob. La prima concessione apostolica della messa ed ufficio della B. Margherita, fatta da Pio VI alla diocesi di Transilvania nel 1789, w: Inqiusitio, s. LXXXV-LIXXXVIII.

${ }^{33}$ Papież Pius VI w 1789 r. zaaprobował dla diecezji siedmiogrodzkiej formularz mszy św. o Małgorzacie. Zob. La prima concessione, s. LXXXV-LIXXXVIII.

${ }^{34} 24$ sierpnia 1804 r. Pius VII w porozumieniu z Świętą Kongregacją Obrzędów dokonał rozciągnięcia na cały Zakon Kaznodziejski prawa sprawowania mszy św. i oficjum o Małgorzacie, co oznaczało również uznanie jej kultu jako błogosławionej. Było to niejako uznanie formalne odwiecznego kultu i udzielenie zgody na formalne tytułowanie Małgorzaty błogosławioną. Zob. Estensione della messa ed ufficio a tutto l'Ordine Domenicano nel 1804, e concessioni susseguenti fino ai nostri giorni, w: Inqiusitio, s. LXXXVIII-LXXXIX.

${ }^{35}$ Böle, Żywot bt. Małgorzaty, s 160.

${ }^{36}$ Kard. Justynian Serédi (wł. Jerzy Szapucsek/Sapuček) ur. w 1884 roku w Deáki k. Pozsony (Bratysławy). W 1901 roku wstapił do benedyktynów w Pannonhalmie. W 1908 r. wyświęcony na kapłana. 30 XI 1927 r. mianowany arcybiskupem Ostrzyhomia i Prymasem Wegier. 8 I 1928 r. wyświęcony na biskupa i niebawem kreowany kardynalem. W czasie drugiej wojny światowej wystapił w obronie Żydów. 27 X 1944 r. sprzeciwił sie przejęciu wladzy przez faszystów Ferenca Szálasiego. Wspierał uchodźców polskich na Węgrzech. Był wybitnym uczonym i członkiem Wegierskiej Akademii Nauk. Brał udział w pracach nad Kodeksem Prawa Kanonicznego. Zmarł w Ostrzyhomiu 29 III $1945 \mathrm{r}$. 
cej, iż wiedzieliśmy, że te pragnienia jak najbardziej odpowiadają naszemu, któreśmy podczas wspaniałego trzydziestego czwartego Międzynarodowego Kongresu Eucharystycznego w Budzie, o czym miła pamięć nigdy Nas nie opuści, jako legat zastępca ś. p. Papieża Piusa Jedenastego, z serca wyrazili.

Stąd Święta Kongregacja Rytów wszystkie dokumenty przedłożone przez ukochanego Syna, Benedykta Lenzettiego, Postulatora Generalnego Zak. Kaznodziejskiego i pilnego rzecznika tej sprawy przez Sekcję Historyków zbadała i oświadczyła, że mają siłę przekonywującą; zbadała również i potwierdziła dane o życiu Błogosławionej Małgorzaty, o jej świętości, sławie cudów i publicznym kulcie liturgicznym poprzez stulecia.

Po zebraniu materiału, na posiedzeniu tejże Św. Kongregacji w dniu trzynastym lipca roku bieżącego czcigodni Bracia Nasi Św. Rz. K. Kardynałowie należący do tejże Świętej Kongregacji wysłuchawszy sprawozdania umiłowanego Syna Naszego Rafała Karola także Św. Rz. K. Kardynała Rossiego, [s. 39] kierownika całej sprawy, sprawozdania, które szeroko wykazało, że są dobrze wiadome świętość życia Błogosławionej Małgorzaty i cnoty przez nią zachowywane w stopniu heroicznym, z których przede wszystkim miłość, zapał do modlitwy i ostra pokuta zajaśniały, o kulcie przez lud od dnia zgonu aż prawie do naszych czasów tejże Błogosławionej oddawanym, oraz o zezwoleniu Stolicy Apostolskiej na sprawowanie liturgii, jak również o sławie cudów, którą ona jest ozdobiona; wysłuchawszy także zdania Urzędników, Przełożonych tejże Św. Kongregacji i wszystko głęboko przemyślawszy i roztrząsnąwszy, uznaliśmy, że należy wniesioną Nam prośbę przedłożyć.

My zaś dnia dwudziestego trzeciego tegoż miesiąca wysłuchawszy o tym wszystkim sprawozdania przedstawionego Nam przez czcigodnego Brata Naszego Karola Św. Rz. K. Kardynała Salottiego, Biskupa Prenestii i Swiętej Kongregacji Rytów Prefekta, uznaliśmy życzliwie przyjąć opinię tejże Świętej Kongregacji. Wszystko zatem głęboko i dojrzale przemyślawszy oraz zważywszy z wielkim przekonaniem, na podstawie pełni naszej Władzy Apostolskiej, niniejszym wypowiadamy uroczyście: ze Błogosławiona Małgorzata Dziewica, z królewskiej rodziny Arpadów, Mniszka Zakonu Św. Dominika, jest Święta i do katalogu Świętych ma być wpisana, postanawiajac, że w Martyrologium Rzymskim pamięć jej między Świętymi Dziewicami corocznie z pobożnościq ma być obchodzona w dniu jej urodzin, mianowicie osiemnastego stycznia ${ }^{37}$.

Stąd też uczciwszy pamięć tej Swiętej rocznica, ufamy, że zaiste stanie się, iż Ona, Potomkini rodziny Świętego Pierwszego króla i Apostoła Stefana, płodnej w tylu i tak wielkich Świętych, znowu podejmie przed Bogiem swoje posłannictwo ofiary zadość czyniącej nie tylko za swoją ojczyznę, która słusznie jest uważaną za obrończynię wiary katolickiej i imienia chrześcijańskiego, lecz także za wszystkie narody, tak zacięcie jeszcze teraz między sobą walczące, że pokój oraz ład na sprawiedliwości i miłości Chrystusowej mocno ugruntowany, uzyska swoimi nieustannymi i potężnymi modłami od Najmiłościwszego Pana, Ojca miło-

\footnotetext{
${ }^{37}$ Kursywą ujęta jest formalna formuła kanonizacyjna, którą papież zamieścił w dekretale.
} 
siernego i Boga wszelkiej pociechy, dla pokoleń ludzkich doprowadzonych pod najsłodsze jarzmo Ewangelii.

Wszystko więc, co należało zbadać, dobrze zważywszy, z całą pewnością i na podstawie Naszego Apostolskiego Autorytetu, wszystko razem i poszczególnie, co wyżej powiedzieliśmy, potwierdzamy, nadajemy temu moc, jeszcze raz stwierdzamy i nakazujemy, oraz oznajmiamy całemu katolickiemu Kościołowi.

Temu więc Dekretałowi, który rozkazujemy sporządzić w dwóch egzemplarzach, w odpisie, czy w wyjątkach, także drukowanemu, podpisanemu jednak przez któregoś z naszych Apostolskich Notariuszy i zaopatrzonemu pieczęcią, chcemy, aby nadano zupełnie tę samą wiarę, którą daje się tu obecnemu listowi, gdyby był okazany lub podany.

Jeżeliby zaś ktoś ten List tego Naszego oświadczenia, dekretu, polecenia i woli [s. 40] Naszej ośmielił się osłabić lub lekkomyślnie sprzeciwić mu się, lub wykroczyć przeciw niemu, niech wie, że popadnie w gniew Wszechmogącego Boga i Błogosławionych Apostołów Piotra i Pawła.

Dan w Rzymie pod św. Piotrem roku Pańskiego tysiącznego dziewięćsetnego czterdziestego trzeciego, dnia dziewiętnastego Listopada, w święto Św. Elżbiety, Pontyfikatu Naszego w roku czwartym.

Ja PIUS, Biskup Kościoła Katolickiego

ALOJZY kard. MAGLIONE KAROL kard. SALOTTI

Sekretarz Stanu Św. Rz D. Prefekt

Wincenty Bianchi Cagliesi Józef Wilpert, Dziekan Prot. Apost.

Prezes Kancelarii Apost. Alfons Carinci, Prot. Apost.

Kan. Alfred Liberati, kan. Apost. Pomocnik w studiach

Jerzy Stara Tedde, kan. Apost. Pomocnik w studiach

WYSŁANY

dnia czternastego Stycznia roku piątego

ALFRED MARINI, pieczętny 
An. et . vol. XXXVI 23 Februarii 1944 (Ser. II, v. XI) - Num.

\author{
ACTA APOSTOLICAE SEDIS \\ COMMENTARIUM OFFICIALE
}

Acta Pii PP. XII

LITTERAE DECRETALES

BEATA MARGARITA VIRGO, E REGIA ARPADENSIUM HUNGARICA FA-
MILIA, ORDINIS S. DOMINICI MONIALIS,
SANCTORUM CATALOGO ADSCRIBITUR

PIUS EPISCOPUS

SERVUS SERVORUM DEI

AD PERPETUAM REI MEMORIAM

Maxima inter munera, quae ex Apostolico ministerio, Nobis, licet immeritis, divinitus commissio, obire satagimus, nullum sane gravius, nullum est dulcius, nullum quod maius inter multiplices qiubus nunc premimur curas et anxietates Nobis afferat solacium, quam supremos sacri cultus honores iis decernere fidelibus, qui, dum viverent, omni virtutum genere ad perfectionis usque gradum emicuerint, miraculorum ab omnipotenti Deo ipsorum intercessione, potissimum post eorum obitum, patratorum gloria fulserint, et constantem sanctitudinis famam marito adepti sint. Quod qiudem Romani Pontifices, divino afflante Spiritu, ad nostra usque tempora, toto catholico orbe plaudente, eo maiori sollicitudine ac frequentia praestiterunt, qou numerosioribus apud Deum intercessoribus praeclarisque vitrutum exemplis christiana plebs indigere videretur.

Quos inter iure meritoque accensendam modo duximus Beatam Virginem illam, catholicae Hungaricae gentis decus, Margaritam, Belae Quarti Regis filiam, incliti S. Dominici Ordinis monialem, quae, cum [p. 34] in antiqua cultus possessione exsistat, et de cuius heroicis virtutibus et de miraculis constans sit historicorum fide dignorum communis assertio et continuata prodigiorum fama non deficiat, digna sane videtur, quam Nos, etsi non per formalem et suetam sollemnem canonizationem, suprema tamen sententia Nostra declaremus Sanctam esse, et in Sanctorum album adscribendam decernamus. E regia Arpadensium Hungarica familia, quae sola uno eodemque tertio decimo saeculo quatuor quidem alias praeclaras vitae sanctitate feminas Ecclesiae Dei genuit, videlicet S. Elisabeth, a fel. rec. Gregorio Nono, decessore Nostro, anno millesimo ducentesimo trigesimo quinto inter Sanctos relatam, B. Agnetem Pragensem, eius sobrinam, et Belae Quarti Regis filias, Cunecundem et Iolentam, quarum cultus ab Apostolica Sede confirmatus est, originem duxit Margarita. Anno circiter millesimo ducentesimo quadragesimo secundo, cum Tatrari, Battho duce, Poloniam et Pannoniam ferro ignique vastarent, et Hungaria, tot christifidelium sanguine irrorata, eorum feris- 
simas pateretur vastationes, ex piis parentibus Bela Quarto, Hungarorum Rege, et Maria Lascaris Regina, dalmata receptis arce, nata est Beata Margarita. Conceptam prolem genitores pro regni liberatione suaque salute, quasi piaculum quoddam, si filia nasceretur, eam deo consecrarunt; eorumque preces et vota exaudita sunt; nam, pacatis repente omnibus, Budam ipsi una cum recens nata Margarita remigrare potuerunt. Eam, avito regno tutelarem e materno sinu factam, parens optima, promissi et beneficii memor, ad Vesprimiense sanctimonialium monasterium S. Catharinae Virginis et Martyris «Ordinis S. Dominici» ante annum aetatis quartum deduxit, ut ab ipsa iam tenera aetate regularibus imbueretur consuetudinibus et Deo aptius serviret. Crucis ibi discipula ex corde effecta, domumque regiam prorsus oblita, Margarita docili obedientique animo ita floruit, ut moniales tenerrima eam dilectione prosequentur; atque, praeter aetatem, angelicam in Iesum Christum ac Deiparam Virginem pietatem colebat; ingenuos ostendit mores animique candorem; et illico promeruit ut Rex regum speciem eius concupisceret.

Vix quinque annos nata, una cum sororibus disciplinam recipere voluit, ieiunare et cilicium adhibere. Quare rex pater eius, Hungarica natione contra Tartarorum incursiones operibus munita, ut securius efficaciusque sibi suoque regno divinum auxilium conciliaret, in Danubii insula, quam olim Leporum, hodie S. Margaritae, appellant, ad Beatisssimae Virginis Mariae honorem quoddam monasterium aedificavit, in quo nedum pias sacras virgines collocandas curavit, quae, veluti hostiae viventes, Deo soli se devoverent, eiusque ac Deiparae laudes canerent, [p. 35] sed suam etiam filiam, Margaritam, quam inter alios suos liberos eo teneriori amplexabatur affectu, qou certiora piae Deo placite conversationis in ea primordia cernebat.

Interim illa, quae sua fecisse visa est Apostoli verba: Existimo omnia detrimentum esse propter eminentem scientiam Iesu Christi Domini mei: propter quem omnia detrimentum feci et arbitror ut stercora, ut christum lucrifaciam, honestis cuiusdam Poloniae Principis recusatis nuptiis, duodennis vota solemnia coram venerabili Magistro Ordinis Humberto nuncupavit. Adhuc autem ab Othocaro, Bohemiae Rege, serio expetita, ut suam Divino Sponso fidem datam totis viribus intactam servaret, ad illam et quamvis aliam occasionem importunae sponsalium instantiae auferendam, se christo palam desponsatam prodere voluit et sacrum capitis velamen enixe postulavit, et quarta decima die Iunii mensis, anno millesimo ducentesimo sexagesimo primo ab Archiepiscopo Strigoniensi, adstantibus quoque Episcopis Waciensi et Nitriensi, nec non plurimis ecclesiasticis viris, as $\mathrm{S}$. Elisabeth amitae suae aram, maximo cum gaudio, obtinuit. Virginum Sponso ita consecrata, mundi suique contemptu, et carnis maceratione, Regi ipsi Martyrum impigre studuit assimilari. Deterrimis semper amicta vestibus, abiectisque muneribus inhians, verrere domum, sordes abstergere, parare cibos et gravi saepe pondere onerari in deliciis habuit. Aegrotis sororibus et ancillis ipsis, quarum aliquando morbo infici ceterae timerent, tali inserviebat caritate et abiectionis desiderio, ut gravia cuncta et infima officia erga ipsas sibi unice arrogaret.

Manus gelu et cubitos ac genua humi adhaesione tumescere et dilacerari nil reputans, attritum multo ieiunio corpus cilicio, flagris et insomni nocte, acriter divexabat, tum sextis maxime feriis ac pridie Christi Domini et Deiparae Virginis 
solemnitatum, tum diebus quindecim Paschali sacramento praeviis. Passionis item mysteria cum singultu recolebat et martyrii aestu flagrabat. Coram Christo Iesu velis eucharisticis abscondito, aut ad crucem depicto, libentius et ad multas quotidie horas, cor suum effundens, ubique tamen et fere sine intermissione orabat, praescriptae divinae laudi integrum non raro addens psalterium, ad Deum Patrem orationes, vel ad Patraclitum Spiritum, aut dilectissimae sibi Dei parenti Virgini salutationes. Virtutes omnes, theologales in primis, in gradu heroico, impenso studio excoluisse fertur et in earum exercitio ad mortem usque constanter perseverasse, ita ut maximo esset ceteris ad virtutem incitamento.

Margaritae virtus praefulsisse videtur acerrimi belli tempore, quod inter eius patrem Belam Quartum Regem fratremque Stephanum propter [p. 36] regni gubernationem et ad illud successionem ortum est et per quaruor circiter annos perduravit, in quo, confuso omni ordine iustitiae et postposito Dei timore tam in praelatis quam in baronibus, multa millia innocentium absque iustitiae aequitate perierunt.

Tam infausta calamitas Margaritae animum ita excruciavit, ut lacrimae ipsi fuerint panis die ac nocte: paternam enim prospiciebat familiam simultatibus ac discidio tam acriter dilaniatam, populum periclitantem sine sexus et aetatis discretione oppressum, sanctam quoque matrem Ecclesiam, non tantum in huius regni, sed in aliis etiam christianitatis partibus, tirannide conculcari et dilacerari, claustra et religiosorum loca absque habitatore desolari, divina omnia humanaque iura inique permisceri. Ut Omnipotentis Dei iram placaret suaeque genti divinam conciliaret clementiam, uberius ipsa flebat suumque corpus macerabat ieiuniis, vestita cilicio, quasi omnium tam inique circa Deum agentium lugens peccata et oppressorum deflens calamitates totaque precibus apud Deum instabat, ut dextera suae potentiae, obstructis et refrenatis iniquorum potentiis, defenderet innocentes sanctamque matrem Ecclesiam, suo pretioso sanguine congregatam, Dominus Iesus Christus.

Porro Margarita actionem suam non coërcuit tantum intra incensissimas ad Deum precationes et durissimam poenitentiam, verum etiam auctoritate aut dignitate insignito, patratam; quod effecit ut illa dubitavit apertissime exprobrare iniquitatem a quocumque, altissima etiam auctoritate aut dignitate insignito, patratam; quod effecit ut illa patris regis iram in se converterit atque eius persecutionem quoque, blanditiis prius spretis, pati debuerit; quam autem ipsa minime metuit et impavida tulit, qiun opus suum intermitteret humanam pravitatem reprobandi simulque adversariorum animos pacificandi.

Eius preces abundantissime ad Deum effusae, cum virginei sui corporis maceratione coniunctae, ab Altissimo tandem exauditae sunt, patrem inter et fratrem pace restituta, quae in Leporum insula, in ipso monasterio a Margarita sanctificato, solemniter sancita est anno Domini millesimo ducentesimo sexagesimo sexto.

Ad magis magisque firmandam regni tranquillitatem Bela Rex familiam suam affinitate coniungendam censuit cum Carolo Andegavensi Comite, qui, anno ducentesimo sexagesimo sexto supra millesimum, Neapolis Rex factus est; ac propterea cum ipso filiae suae Margaritae nuptias proposuit, adiciens se a Clemente Papa Quarto a religionis votis pro ea facile obtenturum dispensationem. Margarita 
et hac tertia vice propositas nuptias illico recusavit, libere respondens servare velle vir ginitatem [p. 37] suam Domino Iesu Christo. Et Divinus hic Sponsus, fidelis semper et generosior, qui in famulae suae corde dulcem fecerat mansionem, eam supernis donis uberrime cumulavit, passionis suae sociam atque consolationis et potestatis consortem reddidit viventem pariter et post mortem.

Illa namque fertur vel a pueritia prophetizans, et inter sacra sensibus avocari solita, cordium arcana cognovisse, sanationes et prodigia non pauca divina facultate perpetrasse.

Proximae tandem mortis praescia, ardenter petiit et, sicut desideraverat, pluries recepit extrema Ecclesiae sacramenta, quibus angelica pietate susceptis, in festo Sanctae Priscae, anno millesimo ducentesimo septuagesimo, lustris sex aetatis nondum expletis, diademati Christi innexa Margarita caelos intravit. Virgineum eius corpus futurae resurrectionis decus quoddam cum suavi fragrantia prae se ferens, solemni pompa sepulcro illatum, supplicantium morbis, uti refertur, medicina fuit: et multa prodigia narrantur et gratiae concessae, Dei Famulae intercessione invocata, usque ad praesens.

Nil ergo mirum est quod Margaritae nomen celeberrimum est in Hungarica regione, clarumque in aliis: terrenam namque patriam heroicarum virtutum suavitate, atque sanctitudinis lumine atque miraculorum fama ipsa illustravit; sed extra quoque patriae fines per inclitum praecipue Praedicatorum Ordinem, qui singulari se Beatae protectione auctum gloriatur, nomen illud gloriosum evasit sive legendis, quae de margarita uti de sancta statim post eius obitum evulgatae sunt, sive maxime ex processu apostolica auctoritate sex post anno a regiae Virginis morte constructo, in quo saepe saepius Beatae vel Sanctae titulus a testibus Margaritae tribuitur, ab ecclesiastica, suprema quoque, auctoritate sancitus.

Cultus autem huic Dei Famulae exhibitus, statim post pretiosum eius obitum inceptus, novo semper lumine coruscans, ad nostra usque tempora pervenit. Etenim luce clarius eruitur tum ex biographicis historiis, variis linguis concinnatis; tum ex monumentis; quae inter pretiosum pallium extat ab Elisabeth, Hungarica regina, uti fertur, Nostrae Basilicae S. Petri anno millesimo trecentesimo quadragesimo tertio donatum, in quo, una cum B. Virginis Mariae, Ss. Apostolorum Petri et Pauli, quatuor Hungaricae regiae familiae Sanctorum imaginibus, Margaritae quoque filiae Regis Hungariae conspiciebatur imago, cui quoque Sanctae titulus tribuebatur; tum ex fidelium veneratione erga Famulae Dei sepulcrum et reliquias; tum ex pluribus Beatae depictis imaginibus, decurrente aetate auctis, quibus publicus venerationis cultus [p. 38] exhibetur; tum ex festivitate, in qua Beatae memoriam Hungaricus populus recolit eique suam exhibet ardentem devotionem.

Eruitur potissimum ex facultate ab Apostolica Sede concessa officium recitandi et Missam celebrandi de Beata illa Virgine, primum Transilvaniensi Dioecesi a Decessore Nostro Pio papa Sexto anno millesimo septigentesimo octogesimo nono; quam facultatem Pius Papa Septimus universo Praedicatorum Ordini extendit anno millesimo octingentesimo quarto; quare Beatae festum prima vice ab eodem Ordine in hac ipsa Nostra Urbe, in Basilica S. Mariae supra Minervam, vicesima sexta die Ianuarii mensis, anno insequenti magna cum pompa celebratum est. 
Quum itaque ad Beatae Margaritae aequipollentem canonizationem decernendam, iuxta sapientissimi Praedecessoris Nostri, Benedicti Papae XIV, normas, requisitae condiciones concurrere viderentur, dilectus Filius Noster Iustinianus S. R. E. Cardinalis Serédi, Princeps Primas Hungariae et Archiepiscopus Strigoniensis, omnium etiam nomine Hungariae Antistitum, dilecti Filii Hungarici Regni Moderatores et Principes ac tota fere Hungarorum Natio, una cum Ordinis Praedicatorum Magistro Generali, et innumeris catholici orbis Cardinalibus, Episcopis et religiosis familiis, supplicia vota Nobis porrexerunt, intantissime postulantes ut de Apostolicae Nostrae potestatis plenitudine Beatam Margaritam Virginem Sanctorum albo adscribere dignemur.

Nos igitur, haec vota benigne excipientes, Sacrae Rituum Congregationi rem plene cognoscendam expediendamque lubentissime commisimus, eo vel magis qiua vota ipsa Nostro etiam voto quam maxime respondere vidimus, quod in magnifica Congressione Eucharistica Internationali trigesimaquarta Budae celebrata, cuius gratissima nunquam ex animo Nostro memoria discedet, Nos, tunc Legatus a Letere fel. rec. Pii Papae Undecimi, ex corde promere voluimus.

Sacra itaque Rituum Congregatio per Sectionem Historicam documenta omnia, a dilecto Filio Benedicto Lenzetti, Ord. Praedicatorum Postulatore Generali ac sedulissimo huius Causae Procuratore, allata. Ad criticae scientiae normas, ea qua par est diligentia ribravit, eademque probandi vi pollere declaravit; nec non de Beatae Margaritae vita, deque eius sanctitatis, miraculorum fama ac publico et liturgico cultu per saeculorum decursum amplisse investigavit et comprobavit.

Quibus praehabitis, in eiusdem S. Congregationis comitiis die tertia decima Iulii mensis huius anni, venerabiles Fratres Nostri S. R. E. Cardinales eidem Sacrae Congregationi illi praepositi, audita dilecti Filii Nostri Raphaëlis Caroli eiusdem S. R. E. Cardinalis Rossi, Causae [p. 39] Ponentis, relatione, qua amplissime ostendit constare de Beatae Margaritae vitae sanctitate, de virtutibus ab eadem in heroico gradu exercitis, quarum praecipue caritas, precandi studium et arctissima poenitentia enituere, de cultu sive a populo ab obitus die ad nostra usque tempora eidem Beatae exhibito, sive etiam liturgico ab Apostolica Sede indulto, nec non de miraculorum fama, qua Ipsa honestatur; auditis quoque Officialium eiusdem S. Congregationis Praelatorum votis, omnibus mature perpensis et discussis, pro oblatis precibus excipiendis Nobis proponendum censuerunt.

Nos autem die tertia et vicesima insequenti, de his omnibus relatione Nobis facta per venerabilem Fratrem Nostrum Carolum S. R. E. Cardinalem Salotti, Episcopum Praenestinum et Sacrorum Rituum Congregationis Praefectum, Sacrae eiusdem Congregationis sententiam lubenti animo excipiendam duximus. Omnibus itaque mature perpensis, certa scientia, de Apostolicae potestatis Nostrae plenitudine, tenore praesentium, solemniter edicimus: Beatam Margaritam Virginem, e regia Arpadensium familia, Ordinis $S$. Dominici Monialem, Sanctam esse et Sanctorum catalogo adscribendam, statuentes in Martyrologio Romano illius memoriam quotannis die eius natali, nempe duodevicesima Ianuarii mensis, inter Sanctas Virgines pia devotiones recoli debere.

Ita igitur novensilis huius Sanctae a Nobis consecrata memoria, profecto fore confidimus ut Ipsa, Sancti Protoregis et Apostoli Stephani familiae, tot tantisque 
fecundae Sanctis, soboles, suam apud Deum propitiatricis hostiae missionem resumat, non pro dilectissima sibi patria tantum, quae merito catholicae fidei et christiani nominis propugnaculum habetur, sed et pro cunctis nationibus tam acriter adhuc inter se conflictantibus; et tranqiullitatem ac pacem, in iustitia et caritate Christi firmiter fundatam, a pientissimo Domino, Patre misericordiarum et Deo totius consolationis, humano generi, suavissimo Evangelii iugo subducto, assiduis suis potentibusque assequatur precibus.

Omnibus itaque, quae inspicienda erant, bene perpensis, certa scientia, Apostolica Auctoritatis Nostrae plenitudine, omnia et singula quae supra diximus confirmamus, roboramus, denuo statuimus ac praecipimus, universaeque catholicae Ecclesiae denunciamus.

Harum vero Litterarum Decretalium, quas duplici originali expediri iubemus, transumptis sive excerrptis et sigillo munitis, eadem prorsus volumus haberi fidem, quae hisce praesentibus haberetur, si exhibitae vel ostensae forent.

$\mathrm{Si}$ quis autem has Litteras declarationis, decreti, mandati et voluntatis [p.40] Nostrae infringere vel ausu temerario eis contraire aut attentare praesumpserit, indignationem Omnipotentis Dei et Beatorum Apostolorum Petri et Pauli se noverit incursurum.

Datum Romae apud S. Petrum, anno Domini millesimo nongentesimo quadragesimo tertio, die decima nona Novembris mensis, in festo S. Elisabeth, Pontificatus Nostri anno quinot

Ego PIUS, Catholicae Ecclesiae Episcopus

\section{ALOYSIUS Card. MAGLIONE CAROLUS Card. SALOTTI A Secretis Status S. R C. Praefectus}

Wincentius Bianchi Cagliesi Joseph Wilpert, Decanus Prot. Apost. Cancellarae Apost. Regens. Alfonsus Carinci, Prot. Apost.

Can. Alfridus Liberati, Canc. Apost. Adiutor a studiis.

Georgius Stara Tedde, Canc. Apost. Adiutor a studiis.

\section{EXPEDITA}

die quartadecima Ianuarii, anno quinto ALFRIDUS MARINI, Plumbator 